\title{
Introduction to this special issue on the ecology and evolution of the Carpathian flora
}

\author{
Filip Kolář • Michal Hájek • Petra Hájková • \\ Jan Roleček • Marek Slovák • Milan Valachovič
}

Published online: 19 October 2018

(C) Institute of Botany, Academy of Sciences of the Czech Republic 2018

The Carpathian Mountains, spanning from eastern Czechia through southern Poland, Slovakia and eastern Ukraine to Romania, are one of the least known mountainous diversity hotspots in Europe. Besides a unique diversity of endemic species and vegetation units, they also host numerous relicts from various time periods and had likely served as an important refugium for the boreal and temperate biota. For decades, the Carpathians have attracted botanists from surrounding countries, and their interest is not diminishing. This issue of Folia Geobotanica summarizes research presented at a joint conference of the Czech and Slovak Botanical Societies, held in the autumn of 2016 in Prague. The event was

\section{F. Kolář $(\bowtie) \cdot$ M. Slovák}

Department of Botany, Faculty of Science, Charles University, Benátská 2, 12801 Prague, Czech Republic

e-mail: filip.kolar@gmail.com

M. Hájek · P. Hájková · J. Roleček

Department of Botany and Zoology, Faculty of Science, Masaryk University, Kotlářská 267/2, 61137 Brno, Czech Republic

\section{P. Hájková}

Laboratory of Palaeoecology, Institute of Botany, Czech Academy of Sciences, Lidická 25/27, 60200 Brno, Czech Republic

J. Roleček

Department of Vegetation Ecology, Institute of Botany, Czech Academy of Sciences, Lidická 25/27, 60200 Brno, Czech Republic

M. Slovák · M. Valachovič

Plant Science and Biodiversity Centre, Slovak Academy of

Sciences, Dúbravská cesta 9, 84523 Bratislava, Slovakia focused on describing Carpathian plant diversity from various angles, ranging from historical and floristic aspects to genetic variation and the structure of plant communities. The contributions made at this conference constitute the main body of the present issue (Dítě et al. 2018; Jamrichová et al. 2018; Peterka et al. 2018; Těšitel et al. 2018) and are complemented by vegetation surveys carried out in the Western Carpathians (Czortek et al. 2018; Kalníková et al. 2018; Medvecká et al. 2018).

The articles composing this issue deal with a wide range of topics linked to the Carpathian flora and vegetation, namely the history and structure of Carpathian mires, the biogeography and phylogeography of relict species, and vegetation dynamics. Jamrichová et al. (2018) present novel palaeoecological data from two mires in the southwestern part of the Western Carpathians and reconstruct local vegetation succession and human impact in the region. Peterka et al. (2018) offer a biogeographical and historical perspective on quaking rich fen vegetation, which is rare and declining in the Carpathians, and draw comparisons with other regions of Europe. Dítě et al. (2018) present a critical assessment of the status of relict species in the Western Carpathians and provide a list of relict plant taxa occurring in this region. Těšitel et al. (2018) combined phylogeography and vegetation sampling to address questions concerning the history of disjunct Carpathian populations of the Pedicularis exaltata $P$. hacquetii species complex and relationships among its members. Finally, three studies examine the composition and dynamics of various vegetation types in the 
Western Carpathians: Kalníková et al. (2018) describe succession on gravel bars, Czortek et al. (2018) bring novel insights into long-term changes in subalpine communities, and Medvecká et al. (2018) investigate factors affecting the spread of alien plants in the Tatra Mountains. We hope that this issue will bring additional attention to this still underexplored region and that it will stimulate further research of the exceptional Carpathian diversity.

\section{References}

Czortek P, Kapfer J, Delimat A, Eycott E, Grytnes J-A, Orczewska A, Ratyńska H, Zięba A, Jaroszewicz B (2018) Plant species composition shifts in the Tatra Mts as a response to environmental change: a resurvey study after 90 years. Folia Geobot 53:1-16. https://doi.org/10.1007/s12224-018-9312-9

Dítě D, Hájek M, Svitková I, Košuthová A, Šoltés R, Kliment J (2018) Glacial-relict symptoms in the Western Carpathian flora. Folia Geobot (this issue)
Jamrichová E, Gálová A, Gašpar A, Horsák M, Frodlová J, Hájek M, Hajnalová M, Hájková P (2018) Holocene development of two calcareous spring fens at the Carpathian-Pannonian interface controlled by climate and human impact. Folia Geobot (this issue)

Kalníková V, Chytrý K, Chytrý M (2018) Early vegetation succession on gravel bars of Czech Carpathian streams. Folia Geobot 53:1-16. https://doi.org/10.1007/s12224-018-9323-6

Medvecká J, Zaliberová M, Májeková J, Senko D, Jarolímek I (2018) Role of infrastructure and other environmental factors affecting the distribution of alien plants in the Tatra Mts. Folia Geobot 53:1-16. https://doi.org/10.1007/s12224-0189319-2

Peterka T, Hájek M, Dítě D, Hájková P, Palpurina P, Goia I, Grulich V, Kalníková V, Plesková Z, Šímová A, Štechová T (2018) Relict occurrences of boreal brown-moss quaking rich fens in the Carpathians and adjacent territories. Folia Geobot 53:1-12. https://doi.org/10.1007/s12224-018-9318-3

Těšitel J, Vratislavská M, Novák P, Chorney II, Roleček J (2018) Merging of Pedicularis exaltata and P. hacquetii in the Carpathians: from local history to regional phylogeography based on complex evidence. Folia Geobot (this issue) 